\title{
A Study on the Readability of the English Versions of Chinese Red Tourism Based on Readers' Response
}

Huijia Shen (Corresponding author)

Zhejiang University of Finance \& Economics Dongfang College, China

Email: shjmonica@163.com

Received: 24/01/2021

Accepted: 08/04/2021

Published: 01/05/2021

Volume: 2 Issue: 3

How to cite this paper: Shen, H. (2021). A Study on the Readability of the English Versions of Chinese Red Tourism Based on Readers' Response. Journal of Practical Studies in Education, 2(3), 5-11

DOI: https://doi.org/10.46809/jpse.v2i3.23

Copyright (C 2020 by author(s) and Global Talent Academy Ltd. This work is licensed under the Creative Commons Attribution International License (CC BY 4.0).

http://creativecommons.org/licenses/by/4.0/

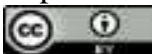

\begin{abstract}
The year 2021 is the 100th anniversary of the founding of the Communist Party of China. With the rapid development of red tourism in China, the importance of red publicity translation has become increasingly prominent. How to evaluate the readability of red publicity translation has gradually become a hot issue. Taking the English versions of Museum of the War of Chinese People's Resistance against Japanese Aggression, Jinggangshan Revolution Museum, Chongqing Hongyan Revolution History Museum and Nanhu Revolution Memorial Museum as examples, this article collects 16 target language readers' feedbacks on the red tourism publicity translations through questionnaire and interview. The results show that the readability of the translation is influenced by many factors such as the quality of the text, the length of the text and the background of the readers. Due to the lack of understanding of the target language and text functions, there are various problems in the translation of words, sentences and discourses. Studies show that the emphasis of the importance of target language readers in quality assessment of red tourism publicity texts may effectively prevent researchers from substituting their own subjective judgments for readers' feedback, thus; it is important to provide a more readable publicity text. This article attempts to improve the readability of red publicity translation, so as to better promote Chinese red tourism and spread Chinese red culture.
\end{abstract}

Keywords: Chinese Red Tourism, C-E Translation; Readability, Empirical Research, Reader Response

\section{Introduction}

Red tourism refers to a kind of tourism activity which takes revolutionary commemoration sites, monuments and revolutionary spirit as connotation, combines cultural landscape with natural landscape, and helps people understand relevant historical and cultural knowledge. The year 2021 is the $100^{\text {th }}$ anniversary of the founding of the Communist Party of China. As a special tourism and cultural product, red tourism has distinct Chinese characteristics and cultural features, so the translation of red tourism becomes more and more important. In recent years, the translation of red tourism materials has been discussed from the perspectives of functionalism, eco translatology and adaptation theory, among which functionalism is the most prominent one (Fu, 2014). This theory emphasizes "target-reader-orientedness" which is especially suitable for the translation of all kinds of applied texts (Nord, 2006). Under the guidance of this theory, there have been some beneficial attempts with distinctive regional characteristics. It is worth noting that although functionalist schools generally agree on the 
importance of target language readers in the process of translation, practical studies often exclude it. In addition, most of the existing literatures focus on speculation when discussing textual errors. Few scholars use empirical research or investigation to collect data, so the scientific aspect of research methods needs to be improved (Tian, 2016). In view of this, this article will take the English versions of Museum of the War of Chinese People's Resistance against Japanese Aggression, Jinggangshan Revolution Museum, Chongqing Hongyan Revolution History Museum and Nanhu Revolution Memorial Museum as examples to study the readability and problems of the text from the perspective of target-readers. Through the study of the readability of Chinese red tourism translation, this article hopes to enhance foreigners' acceptance of Chinese red culture and promote the cultural exchange between China and the west. On the occasion of the centenary of the Communist Party of China, we can better show Chinese culture and enhance the national cultural soft power.

\section{Research Methods}

The four materials used in this article are real corpus. Material one is the English introduction of Museum of the War of Chinese People's Resistance against Japanese Aggression (806 words), material two is the English introduction of Jinggangshan Revolution Museum brochure (384 words), material three is the English introduction of Chongqing Hongyan Revolution History Museum (344 words), and material four is the English introduction on the exhibition hall of Nanhu Revolution Memorial Museum (356 words).

A total of 16 native speakers or common language users participated in the study, ranging in age from 17 to 61 years old, with an average age of 33 years old.

Table 1. Statistics of subjects' basic information

\begin{tabular}{|c|c|c|c|c|c|c|c|}
\hline variable & category & $\begin{array}{l}\text { number } \\
\text { of } \\
\text { people }\end{array}$ & proportion & variable & category & $\begin{array}{l}\text { number } \\
\text { of } \\
\text { people }\end{array}$ & proportion \\
\hline \multirow[t]{2}{*}{ gender } & male & 6 & $37.5 \%$ & \multirow[t]{2}{*}{ age } & $20-40$ & 11 & $68.75 \%$ \\
\hline & female & 10 & $62.5 \%$ & & $40+$ & 5 & $31.25 \%$ \\
\hline \multirow[t]{4}{*}{ education } & high school & 3 & $18.75 \%$ & \multirow[t]{4}{*}{ nationality } & UK & 8 & $50 \%$ \\
\hline & undergraduate & 9 & $56.25 \%$ & & USA & 4 & $25 \%$ \\
\hline & \multirow[t]{2}{*}{ postgraduate } & \multirow[t]{2}{*}{4} & \multirow[t]{2}{*}{$25 \%$} & & France & 2 & $12.5 \%$ \\
\hline & & & & & Italy & 2 & $12.5 \%$ \\
\hline \multirow[t]{4}{*}{ red culture } & familiar & 1 & $6.25 \%$ & \multirow{4}{*}{$\begin{array}{l}\text { travel in } \\
\text { China }\end{array}$} & \multirow[t]{2}{*}{ yes } & \multirow[t]{2}{*}{1} & \multirow[t]{2}{*}{$6.25 \%$} \\
\hline & known & 5 & $31.25 \%$ & & & & \\
\hline & unfamiliar & 9 & $56.25 \%$ & & \multirow[t]{2}{*}{ no } & \multirow[t]{2}{*}{15} & \multirow[t]{2}{*}{$93.75 \%$} \\
\hline & unknown & 1 & $6.25 \%$ & & & & \\
\hline
\end{tabular}

This article mainly collects data through questionnaire and interview. During the questionnaire, the subjects first read through the four materials and marked the difficulties and problems. After reading, they make an overall evaluation of the readability of these texts. Five of them also participated in the one-on-one structured interview.

\section{Results and Discussion}

\subsection{Factors Affecting the Readability of Translation}

This study shows that text quality, text length and reader's background may affect the readability of the translation. The primary factor affecting the reading effect is the quality of the text. All the subjects knew that the general idea of the text was related to the revolution and scenery of these museums, but they didn't understand some specific words and paragraphs. Four subjects pointed out that the translation was obscure and they had no interest in reading. The second factor is the length of the text. Short texts are easier to understand than long ones. Six participants agreed that the length of material two, three and four was shorter and easy reading, and the length of material one was longer and more difficult. Thirdly, the differences in cultural background lead to great differences in the interpretation of the text.

Most of the subjects were unfamiliar with the history of Chinese revolution. Most of them only knew about Chairman Mao, but not Marshal Zhu De. They also knew nothing about "A single spark can start a prairie fire." and "Political power comes out of the barrel of a gun". Seven participants thought that the contents related to the revolution needed to be annotated. Otherwise it would be difficult to understand. In addition, the subjects' Chinese proficiency will also affect the reading effect. For example,

Example 1:

Original version: 纪念碑主碑的造型突出“山”的形象。

Translated version: The model of the main monument was built into a shape of mountain (which is called Shan in Chinese character). 
Except for one subject, most of the subjects' Chinese still generally remain at a relatively low level or do not understand Chinese at all, so they cannot understand example 1. The Chinese pinyin "Shan" is not enough to connect the shape of the monument with the pictograph "Shan". It is necessary to point out the connection between the two when translating.

3.2. Translation Problems

The analysis of readers' opinions shows that the problems of translation mainly focus on vocabulary, sentence and discourse.

3.2.1. Vocabulary

According to the feedback of the participants, lexical errors are reflected in the misuse of grammatical words and vocabularies, involving four types of meanings: conceptual meaning, collocation meaning, extended meaning and associative meaning. Conceptual meaning refers to the logical, cognitive or referential meaning of a word. Collocation meaning refers to the habitual use or combination of words. Extended meaning is derived from conceptual meaning and is usually closely related to metaphor. Associative meaning refers to the meaning caused by the connection between conceptual meaning and real life experience (Newmark, 1988).

The problems of grammatical words mainly focus on the conceptual meaning and collocation meaning of vocabulary. Five participants pointed out that word classes were used inappropriately in all the four texts.

Example 2:

Original version: 南湖革命纪念馆、重庆红岩革命历史博物馆、井冈山革命纪念馆

Translated version: Nanhu revolution memorial museum, Chongqing Hongyan Revolution History Museum, Jinggangshan Revolution Museum.

“革命” in “革命纪念馆” should be translated as an adjective, because two adjectives “革命的” and “纪念的” can be put in front of an English noun. According to the Oxford Advanced Learner's English-Chinese Dictionary(2004), the word "revolution" is a noun, and its adjective is "revolutionary". Therefore, the above three museums should be translated into "Revolutionary Memorial Museum" or "Revolutionary History Museum".

Different from grammatical words, the conceptual meaning errors of lexical words are manifested in fuzzy reference and confusion of synonyms, for example:

Example 3:

Original version: 红岩是国家 AAAA 级旅游景区。

Translated version: Hongyan Museum won AAAA National Tourist Attraction.

Nine participants pointed out that the "AAAA" in the sentence was vague, and some people even mistakenly thought that it was referred to "four-star" in hotel star rating. In fact, China's tourist attractions are divided into five levels according to the quality, of which 5A is the highest level. Due to the lack of this evaluation system in English speaking countries, literal translation is easy to cause misunderstanding, so free translation is recommended.

In addition, six participants pointed out that there were some improper collocations in the text, such as Example 4:

Original version: 在党中央、国务院的亲切关怀下,

Translated version: With the tender care of the CPC Central Committee and the State Council...

According to the search results of British National corpus, the word "tender" is rarely used directly with "care". The more common usage is "tender loving care", which means "taking good care". This fixed phrase was originally used to describe nurses who care for others, such as "Mandy had plied her with tender loving care until the teas had come." Now it can also mean the care of indoor plants or the maintenance of old houses, such as "When bill and Jenny bought the garden, it was in need of a lot of tender loving care". None of the above usages can describe the concern of the superior for the subordinate, so the translation of Example 4 is not appropriate. The original text has the meaning of "extraordinary care", so "tender care" should be changed to "great care".

Example 5:

Original version: 1921 年, 中国共产党第一次全国代表大会在南湖的一艘画舫上完成最后的议程, 庄严宣告中国共产 党成立，从此，南湖成为了全国人民向往的革命圣地。

Translated version: In 1921, the 1st Congress of the CPC was held on a tourism boat, where the final agenda was completed, announcing the establishing of CPC, Nanhu has become a scared revolutionary shrine in the heart of all Chinese people.

Eight participants pointed out that they seldom use "in the heart of all people", they usually use "in the mind of" or "in the eyes of". In the process of translation, we are too rigidly bound to the original Chinese words, and mechanically translate them literally. "Chinglish" is influenced by Chinese thinking and cultural background, and its readability is poor.

The collocation error also reflects that the translation does not distinguish different levels of concepts. Example 6:

Original version:（井冈山）是集历史、文化、园林、雕塑于一体的人文景观。

Translated version: The landscape mixed with history, culture, gardens and sculpture.

Four readers think that Example 6 is wrong, because parks and sculptures belong to the specific components of landscape, while history and culture are the abstract connotations of landscape. "Parks and sculptures" and "history and culture" refer to objects that are not at the same level, and they cannot be juxtaposed. 
The following uses the translation of “千里罗霄之腹” to illustrate the differences between extended meaning and associative meaning

Example 7:

Original version: 千里罗霄之腹。

Translated version: The belly of Trinidad Luoxiao Mountains

According to the Modern Chinese Dictionary(2002), “腹” is a part of the trunk of human and vertebrate. Because this part is located in the center of the trunk, it can be extended to “central part”, such as “腹城” (the central part of city), “腹胜” (the rich area in the center). In other words, “腹” has both conceptual and extended meanings. However, the English word “belly" has only conceptual meaning, so all readers can't understand "belly of mountains" in Example 7. In this example, the word "Trinidad" has associative meaning errors. According to Wikipedia, "Trinidad" is from Spanish and means "Trinity". It refers to a small island in the West Indies, which got its name from its two parallel peaks. One subject speculated that there were three peaks in Luoxiao Mountain, and Jinggang Mountain was only one of them. This explanation was not consistent with the fact. It is worth mentioning that the translation of "Trinidad" from Hong Kong and Taiwan is “千里达”, in which the word “千里（Qianli）" is only transliterated. Influenced by this translation, the translator mistakenly thinks that "Trinidad" means rolling mountains. Therefore, the translation of “千里罗霄” into “Trinidad Luoxia Mountains” will mislead the readers.

Example 8:

Original version: (红军)点燃了中国革命的星星之火。

Translated version: The Red Army ignited a single spark of Chinese revolution.

The translated version of "Red Army" by foreignization does not seem to translate the connotation of it. "Red" in Western culture stands for bloody and brutality which is different from the connotation of red in traditional Chinese culture.

3.2.2. Sentence

Almost all the subjects pointed out the sentence errors in the translation were mainly grammatical errors and sometimes errors in meaning. Grammatical errors are mainly related to predicate verbs, tenses, singular and plural numbers and nouns. For example, some sentences lack predicate verbs, while others have too many verbs:

Example 9 :

Original version: 上世纪二十年代末，毛泽东、朱德等老一辈无产阶级革命家率领中国工农红军来到这里。

Translated version: The late 1920s, Mao Zedong, Zhu De and Other older generation proletarian revolutionaries led the Red Army came here.

Only one predicate is allowed in an English sentence, while the two predicates "led" and "came" appear in example 9, which is grammatical wrong and needs to be adjusted.

Example 10:

Original version: 1987 年投入使用后, 先后接待了日本前首相村山富市等 10 多个国家的重要政要和 80 多个国家和地 区的 30 多万名游客。

Translated version: After it was put into service in 1987, it has received important politicians from more than 10 countries, including former Japanese Prime Minister Tomiichi Murayama, and more than 300,000 visitors from more than 80 countries and regions.

The word "after" means "If something happens after a particular date or event, it happens during the period of time that follows that date or event." The present perfect tense of the verb means the result of an action from the past to the present. Since "after" represents a time point, the predicate verb in the main sentence cannot be continued. Therefore, if there is an adverbial clause of time guided by "after", the predicate verb in the main sentence cannot use the present perfect tense, but can only use the past tense or the future tense. We can use "since" instead of "after" in the perfect tense.

Example 11:

Original version: 该馆致力于红岩革命文化遗产保护、革命文化资源研究、红岩精神探索、革命历史和科学文化知识 传播，设有重庆红岩革命纪念馆、重庆歌乐山革命纪念馆和中国民主党派历史陈列馆等文化遗产群。

Translated version: Dedicated to Hongyan revolutionary culture heritages protection, revolutionary culture resource study, Hongyan Spirit exploration, and revolutionary history and scientific cultural knowledge dissemination, the museum has Chongqing Hongyan Revolutionary Memorial, Chongqing Gele Mountain Revolutionary Memorial, Historical Exhibition Hall of Democratic Parties in China and some other cultural heritage groups.

When giving examples in Chinese, it is usually to put the content of the example at first, and then add the word "etc.", while in English, it is often to put "such as" before those specific examples.

Example 12:

Original version: 每立方厘米空气中含负氧离子数超过 80000 个。

Translated version: .... and the number of air containing negative oxygen irons in per cubic centimeter is over $80,000 \ldots$

The error in this translation is related to the countability of nouns. The uncountable noun "air" can't be counted, so it can't be used with "the number of".

Another case is that the sentence is grammatically correct, but the meaning is different from the original. For example, 
Example 13:

Original version: 1965 年, 毛泽东同志重上井冈山后, 将碑改成了钢筋混凝土结构.

Translated version: In 1965, Chairman Mao visited Jinggangshan, and then rebuilt the Monument into the reinforced concrete structure.

According to the literal meaning of Example 13, Chairman Mao transformed the monument into a reinforced concrete structure, but he is not the person in charge of the project. In order to avoid misunderstanding, it is suggested to change to passive voice.

3.2.3. Discourse

(1) Paragraph structure

One of the reasons for the difficulty of understanding is that there are too many small clauses. For example, Example 14:

Original version: 中国共产党成立以来, 创造性地把马克思主义与中国实际相结合, 团结带领全国各族人民, 为实现 民族独立和人民解放、国家富强和人民幸福, 艰苦奋斗, 不懈探索, 完成新民主主义革命, 建立人民当家作主的新 中国; 确立社会主义基本制度, 进行社会主义建设, 坚持改革开放, 开创中国特色社会主义道路, 取得了举世瞩目 的伟大成就, 为全面建设小康社会, 实现中华民族伟大复兴开辟了广阔的前景。

Translated version: Since its beginning, the Communist Party of China creatively integrated the basic tenets of Marxism with China's reality, ruled and led Chinese people all ethnic groups to work hard and explore continually for national independence and prosperity as well as the happiness of the people completed the New Democratic Revolution and founded New China with the people as the masters of the country; established the basic system of socialism and carried out socialist construction; and upheld the reform and opening up policy, began the path of socialism with Chinese characteristics and 88 remarkable successes, thus opening up a broad visit for building a moderately prosperous society in all respects and attaining the goal great revolution of Chinese nation.

Example 15:

Original version: 展览以历史照片和实物为主, 辅以山水、油画、雕塑、影像、电影等手段, 突出展示了中国各族人 民的历史，包括在香港、澳门的同胞和华侨，在中国共产党发起的抗日民族统一战线旗帜下，以国共合作为基础， 共同抗击日本帝国主义侵略, 代表中国共产党在战争中的骨干作用, 展示了中华民族为世界反法西斯战争胜利所作 出的巨大牺牲和重要贡献, 深刻揭露了日本侵略者在侵华战争中犯下的滔天罪行。

Translated version: With historic photos and objects and assisted with measures such as landscape, oil paintings, sculptures, visual images and films, the exhibition highlighted the history of the Chinese people of various ethnic groups, including compatriots in Hong Kong and Macao and overseas Chinese jointly fighting the aggression of the Japanese imperialists based on the Kuomintang-Communist cooperation under the banner of anti-Japanese national united front initiated by the Communist Party of China, represented the backbone roles of the Communist Party of China in the war, showed the huge sacrifice and the important contribution of the Chinese nation for the victory of the world's anti-Fascist war, and deeply disclosed the monstrous crimes the Japanese invaders had committed during their aggression against China.

Eleven participants pointed out that these two sentences were too long and contain too much information. They suggested that it should add a full stop to decompose the long sentence into several independent short sentences.

(2) Information Distribution

Example 16:

Original version: 红岩博物馆获得的主要荣誉: 国家 AAAA 级旅游景区、全国十大红色旅游景区、全国爱国主义教 育基地、全国廉政教育基地、全国统一战线传统教育基地、全国地方特色党性教育基地、全国研学旅游示范基地、 全国中小学研学实践教育基地、国家国防教育示范基地、全国机要系统革命传统教育基地、全国“我最向往的党史 纪念地”、全国文化体制改革先进单位、全国文明景区先进单位、全国红色旅游先进单位等。

Translated version: Hongyan Museum won AAAA National Tourist Attraction, National Top Ten Revolutionary Tourism Scenic Spot, National Patriotism Education Demonstration Base, the Incorruptible Education Demonstration Base, United Front History Education Base, National Defense Education Demonstration Base, Party Spirit Education Base With Local Features, the First Batch of the Country's Anti-Japanese War Memorial Sites, Revolutionary Tradition Education Base for Confidential Departments, National Advanced Unit of Cultural System Reform, National Advanced Unit of Civilized Scenic Spot, National Advanced Unit of Revolutionary Tourism, "The People-Satisfied Window" and other honors.

All the subjects could not understand the honorary titles in Example 16, and seven of them thought that the data listed were too much and lack of necessary explanation. As this kind of information has little to do with the topic of the text, it is suggested to delete it.

At the same time, the key points of the translation may not be specific enough. For example, there are three sections in material three. The first section introduces the history of Hongyan, the second section describes the collections and main responsibilities of Hongyan, and the third section describes various honorary titles of Hongyan. As the proportion of each paragraph is roughly the same, most readers do not understand the main point of the text.

(3) Discourse Cohesion and Coherence

There are also some problems of cohesion and coherence. Seven participants clearly pointed out that the repetition of the same words in the same text did not conform to English writing habits. For example, the term "Huangyangjie" is frequently used in the introduction of Huangyangjie monument in material two. 
Example 17:

Original version: 为了纪念黄洋界保卫战取得的伟大胜利, 1960 年, 井冈山人民在黄洋界公路上修筑了木质结构的“ 黄洋界保卫战胜利纪念碑”。

Translated version: In 1960, Jinggangshan people built the wooden-structure "Monument for Huangyangjie Defensive Fight" on the Huangyangjie Road for remembering the great victory of Huangyangjie Defensive Fight.

In order to achieve the diversity of words, different expressions need to be used when expressing the same concept.

(4) Consistency of Words

Seven subjects pointed out that the translated terms were not unified. For example, in material four, “南湖” is translated as "South Lake" in the headline, but it is translated as "Nanhu" in the main body part. Secondly, the unit of measurement is not uniform. For example, the use of "square kilometers", "million acres" and "acres" to represent the area in material one is easy to cause confusion.

(5) Use of Punctuation Marks

There are also some improper uses of punctuation marks in the translation: Example 18:

Original version: 重庆红岩联线文化发展管理中心（重庆红岩革命历史博物馆） [简称：红岩联线管理中心（红岩博 物馆）] 成立于 2007 年 1 月，是重庆市文化和旅游发展委员会直属的全额拨款正局级事业单位。

Translated version: Founded in January. 2007, Chongqing Hongyan Alliance Culture Developing Management Center (Chongqing Hongyan Revolution History Museum) ("Hongyan Alliance" "Hongyan Museum" for short), is a bureau level public institution with full government funding.

Five subjects pointed out that the punctuation marks in the sentence were not used properly. Firstly, the punctuation marks in English date expression in Example 18 were wrong. Secondly, there should be one punctuation mark between the quotation marks of "Hongyan Alliance" and "Hongyan Museum".

Example 19:

Original version: 《西江月·井冈山》

Translated version: "Xijiang Yue·Jinggangshan"

All subjects could not understand the dot in the middle of "Xijiang Yue Jinggangshan". In Chinese, this dot represents the separation dot, which is used to mark the separation between the name of Chinese ancient Ci poem "Xijiangyue" and the title "Jinggangshan". This usage cannot be found in English writing.

Generally speaking, there are some problems in vocabulary, sentence and discourse. The main reasons for these errors are as follows: firstly, translators tend to translate according to the literal meaning because they do not have a thorough understanding of the original Chinese text. Due to the fact that the translated text is too faithful to the original text, it becomes obscure and difficult to understand after being translated into English. Specifically, there is a large amount of information in the translation that is not significant or even redundant to readers, and it fails to highlight the main information (Yao, 2014). Also the text does not provide necessary explanation for the red culture and the language organization of the text does not conform to the writing habits of the target language.

Literal translation shows that the translator has no clear understanding of the target readers and writing purposes. On one hand, the translator lacks the understanding of the readers. In fact, the assumption that the assumed readers of the original texts are not foreign tourists who use English, but Chinese tourists who master English is paradoxical, because Chinese readers can read the original text directly, and they do not need to use the translation to obtain information (Liu, 2011). However, the target language readers are not familiar with the language and culture of the source language, so the same translation is insufficient for them. On the other hand, the translator blurs the boundary between the internal and external publicity texts. Some researchers have pointed out that red tourism publicity texts should focus on "informative function" rather than "vocative function" (Xiao, 2010). The materials selected in this article just do not distinguish these two functions, which directly leads to the promotion of scenic spots and inviting tourists in the external publicity text like what is in the internal publicity text, ignoring the information that readers hope to obtain. As a result, it not only fails to arouse the emotional resonance of the readers, but also confuses them. Those translations fail to fully realize the purpose of external publicity.

Secondly, the negative language transfer is significant. From the above analysis, it can be seen that the translator's choice of words and sentences are largely interfered by the native language (Nida, 1999). Due to the lack of analysis of the deep meaning of words and the substructure of sentences, the language of the translation is not authentic enough and the semantic transmission is not accurate enough, so minor language errors (including punctuation marks) often appear.

In addition, the existing management system also has some problems. The red tourism publicity translation lacks the quality control mechanism (Tao, 2020). After the text is translated, it is directly finalized without the review by target language readers or other translators. 


\section{Conclusion and Suggestions}

This article analyzes the readability of red tourism translation through questionnaire and interview. The results show that factors such as text quality, text length and reader background may affect the readability of the text.

Due to the translator's excessive pursuit of formal correspondence between Chinese and English, ignoring the effective transmission of information, the translation problems in vocabulary, sentence and discourse appear. These problems will directly affect foreign tourists' understanding of Chinese red culture and hinder the development of red tourism industry. Study shows that the emphasis of the importance of target language readers in quality assessment of red tourism publicity texts may effectively prevent researchers from substituting their own subjective judgments for readers' feedback, so as to provide a more readable publicity text.

In view of those problems in the above translations, following suggestions are made: Firstly, different versions are provided according to the readers' cultural background. For readers who don't know much about red culture, it is suggested to introduce the background of the Chinese revolution in detail. As for the readers who are more familiar with the Chinese revolution, it is not necessary to annotate the cultural background knowledge. Secondly, the quality of the translated versions should be strictly controlled. It is suggested that native English speakers should be invited to comment on the readability of the translation, and modify the translated versions according to their opinions. At the same time, foreign language professionals are invited to review the translations of the publicity texts to prevent improper collocation, grammatical errors, semantic errors and other language problems. In addition, it is suggested to adjust the information distribution of the translated versions to highlight the key information, such as deep Chinese revolutionary history and beautiful scenes, and weaken or even remove irrelevant information that is not significant to readers, such as titles of honor and financial status (Tao, 2020). We also need to unify the terms involved in red tourism publicity translation. Finally, we should cultivate translators' cross-cultural awareness. It is suggested to employ experienced foreign language teachers of local universities to train the full-time tour guides in cross-cultural communication and foreign languages.

\section{References}

Fu Y. (2014). Studies on the translation of red tourism publicity from the perspective of functionalism. Journal of Language and Literature, 32(2), 54-59.

Liu Y. (2011). Translation of Red Tourism from the Perspective of Eco-translatology. Foreign Language and Literature, 11(1), 74-76.

Modern Chinese Dictionary (2002). Beijing: China Commerce and Trade Press.

Nord, C. (2006). Text Analysis in Translation: Theory, Methodology, and Didactic Application of a Model for Translation Oriented Text Analysis. Beijing: Foreign Language Teaching and Research Press,

Nida, E. A.(1999). Language, Culture and Translating. Shanghai: Shanghai Foreign Language Education Press.

Newmark, P. (1988). Approaches to Translation. Hertfordshire: Prentice Hall.

Oxford Advanced Learner's English-Chinese Dictionary (2004). Beijing: The Commercial Press.

Reiss, K. (2000). Translation Criticism-Potentials and Limitations: Categories and Criteria for Translation Quality Assessment. New York: American Bible Society.

Tian L. (2016). Translation Strategies of Red Tourism Texts in Yan'an. Journal of Yan'an University (Social Science Edition). 12(4), 98-102.

Tao L. (2020, September11). International communication of red culture translation. Chinese Social Science Today, 4.

Xiao Q. (2010). English Translation of Red Tourism Publicity Materials from the Perspective of Functionalism: Problems and Countermeasures. Shanghai: Shanghai International Studies University.

Yao G. (2014). On C-E translation of Red Tourism Publicity from the Perspective of Adaptation Theory. Journal of Xinyang Normal University (Social Science Edition), 13(3), 80-83. 